\title{
Isolation and Characterization of Bacteria for Amylase Production under Solid State Fermentation Using Damaged Wheat as Substrate
}

\author{
Nadia Razdan* and G.S. Kocher \\ Department of Microbiology \\ Punjab Agricultural University, Ludhiana-141004, India \\ *Corresponding author
}

\section{A B S T R A C T}

\section{Keywords}

Dextrinizing,

Saccharifying,

Inoculum, Bio-

inoculant,

Fermentation

Article Info

Accepted:

08 June 2018

Available Online:

10 July 2018

\begin{abstract}
A bacterial isolate $\left(\mathrm{I}_{5}\right)$ along with Bacillus subtilis and Bacillus circulans was evaluated for extracellular amylase production under SmF and SSF conditions. In SmF (Temperature $28 \pm 2^{\circ} \mathrm{C}, \mathrm{pH}-7$ and inoculum size- $10^{6} \mathrm{cfu} \mathrm{ml}^{-1}$, Time- $96 \mathrm{~h}$ ), maximum saccharifying activity (SA) was observed with Bacillus subtilis $(0.62 \mathrm{IU} / \mathrm{ml} / \mathrm{min})$ followed by isolate $\left(\mathrm{I}_{5}\right)$ $(0.58 \mathrm{IU} / \mathrm{ml} / \mathrm{min})$ and Bacillus circulans $(0.46 \mathrm{IU} / \mathrm{ml} / \mathrm{min})$. Whereas dextrinizing activity (DA) was recorded with Bacillus circulans $(1.69 \mathrm{U} / \mathrm{ml})$, followed by isolate $\left(\mathrm{I}_{5}\right)(1.65 \mathrm{U} / \mathrm{ml})$ and Bacillus subtilis $(1.02 \mathrm{U} / \mathrm{ml})$. In $\operatorname{SSF}(1: 2$ moisture content, incubation time -96 hours, $\mathrm{pH}-7$ inoculum size- $10^{6} \mathrm{cfu} \mathrm{ml^{-1 }}$ Temp- $37^{\circ} \mathrm{C}$ ) using different substrates (potato starch, corn starch, raw wheat flour and rice starch) as carbon sources. Maximum saccharifying activity $(23.10 \mathrm{IU} / \mathrm{ml} / \mathrm{min})$ was expressed by Bacillus circulans in $1 \%$ rice starch at $28 \pm 2^{\circ} \mathrm{C}$. Whereas highest dextrinizing activity was recorded with $1 \%$ corn starch (3.31U/ml). On the basis of the present study, Bacillus circulans being the most potential strain for maximum and cost effective alpha amylase enzyme production at appropriate conditions could be utilized as bio-inoculant in fermentation technology in sustainable manner.
\end{abstract}

\section{Introduction}

Profiling microorganisms with high potential for amylase production in submerged fermentation $(\mathrm{SmF})$ which is synthetic media has been widely recognized due to their myriad applicability in bioethanol production. However, the contents of a synthetic medium are very expensive and uneconomical, so there is urgent need to be replaced with more economically available agricultural, industrial and domestic by products, as they are considered to be good substrates for SSF to produce enzymes.

According to an estimate, 12MT (6\%) of grains are damaged by post-harvest storage due to poor storage facilities and hence damage by insects, rodents, birds and microbial spoilage (Sharon et al., 2014). These infested spoiled grains though unfit for human and animal consumption, possess high starch content which provides an adequate substrate for saccharification by microbial 
alpha- and gluco-amylases for fermentation into ethanol.

SSF holds tremendous potential for the production of enzymes in view of its economic and engineering advantages. It can be of particular relevance in those processes where a crude fermented product may be used as an enzyme source (Pandey et al., 1999). The major critical factors affecting microbial synthesis of enzymes in a SSF system includes selection of a suitable substrate and strains, particle size of the substrate, inoculum concentration, moisture level of the substrate, temperature and $\mathrm{pH}$. Thus it involves the screening of a number of agro-industrial materials for microbial growth and product formation. Currently, a large number of microbial amylases are available commercially and they have almost completely replaced the chemical hydrolysis of starch in the starch processing industry (Pandey et al., 2000). In these respect members of the Bacillus family namely Bacillus licheniformis, Bacillus Stearothermophilus etc. are being best utilized for thermostable alpha amylase production (Rehmanand Saeed, 2015). Though, literature widely reports the use of SSF for the production of enzymes and other products has many advantages over submerged fermentation (Lonsane and Ramesh, 1990).

In the present investigation, a soil isolate amylase producing bacteria was selected and compared for enzyme production under submerged and solid state fermentation conditions using wheat flour as substrate.

\section{Materials and Methods}

\section{Collection of bacterial cultures}

Bacterial cultures, Bacillus subtilis (MTCC 121) and Bacillus circulans (MTCC 7906) were procured from Department of Microbiology, Punjab University, Chandigarh and Industrial Microbiology Laboratory, Department of Microbiology, Punjab Agricultural University, Ludhiana respectively. All the cultures were being maintained on nutrient agar medium and further was sub-cultured once in a month throughout the period of investigation and stored at $4^{\circ} \mathrm{C}$ in refrigerator.

\section{Procurement of agricultural based substrates for SmF and SSF systems}

Damaged wheat grains were procured from different areas of Punjab, milled according to different sieving sizes $(1.4 \mathrm{~mm}, 750$ microns, 355 microns, 180 microns and 70 microns) and further subjected to starch analysis by the method of (Clegg, 1956).

\section{Isolation of amylase producing microorganisms}

The soil samples were collected from vegetable field, PAU, Ludhiana. The bacterial strains were isolated by a serial dilution plate

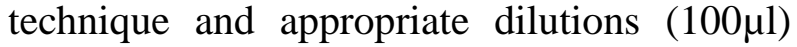
were placed on starch agar as the carbon source for amylolytic bacteria and incubated at $28 \pm 2{ }^{\circ} \mathrm{C}$ for $3-5$ days.

The colonies were selected on the basis of morphological and culture characteristics, then further streaked on their specific media for purification. After purification, bacterial isolates were transferred on nutrient agar slants at $4^{\circ} \mathrm{C}$ temperature. All the bacterial cultures were maintained on nutrient agar and further sub-cultured once in a month throughout the period of investigation and stored at $4^{\circ} \mathrm{C}$ in refrigerator.

\section{Screening of alpha amylase producing microorganisms}

All the bacterial isolates along with two standard cultures (Bacillus subtilis and Bacillus circulans) were screened qualitatively 
for the presence of extracellular amylase production in starch agar media containing composition (soluble starch-10.0gL-1; peptone-10 $\mathrm{gL}^{-1}$; yeast extract-5.0 $\mathrm{gL}^{-1}$; agar$20.00 \mathrm{gL}^{-1}$ ). Formation of clear zones of hydrolysis around the vicinity of the isolates was measured in terms of amylolytic activity index. Amylolytic activity index ( $\left.{ }^{*} \mathrm{AI}\right)$ may be defined as the Ratio between the zone diameter ( $\mathrm{mm})$ - colony diameter $(\mathrm{mm}) /$ colony diameter $(\mathrm{mm})$.

Growth kinetics of amylase producing bacterial isolates along with standard cultures

Amylase producing bacterial isolate $5\left(\mathrm{I}_{5}\right)$ and two standard cultures (Bacillus subtilis and Bacillus circulans) were studied for their growth profile. $100 \mathrm{ml}$ minimal starch medium $\left(\mathrm{Na}_{2} \mathrm{HPO}_{4}-5.8 \mathrm{gL}^{-1} ; \mathrm{KH}_{2} \mathrm{PO}_{4}-3.0 \mathrm{gL}^{-1} ; \mathrm{NaCl}-\right.$ $0.5 \mathrm{gL}^{-1} ; \mathrm{NH}_{4} \mathrm{Cl}-1.0 \mathrm{gL}^{-1} ; \mathrm{MgSO}_{4}(1 \mathrm{M})-2.5$ $\mathrm{ml}, \mathrm{FeCl}_{3}(0.01 \mathrm{M})-2.5 \mathrm{ml}, \quad 10 \%$ Glucose solution-50 ml, $\mathrm{pH}-7$ ) was prepared and autoclaved at $121^{\circ} \mathrm{C}(15 \mathrm{psi})$ for 20 minutes. After cooling the medium at room temperature, each flask containing specific medium was inoculated with a loop full bacterial suspension which shows maximum starch hydrolysis. The inoculated flasks were incubated at $28 \pm 2^{\circ} \mathrm{C}$ under shaking at $120 \mathrm{rpm}$ and samples (0-120h) were collected from each flask to study growth at different time intervals and absorbance was measured by using spectrophotometer at $600 \mathrm{~nm}$ wavelength.

\section{Alpha amylase production}

\section{Submerged fermentation}

On the basis of qualitative screening of amylase production, growth curve and kinetic study of bacterial isolate 5 and two standard cultures (Bacillus subtilis and Bacillus circulans) were selected for qualitative amylase assessment on the basis of extracellular amylase production under submerged fermentation conditions (Temp$28 \pm 2{ }^{\circ} \mathrm{C}, \mathrm{pH}-7$, inoculum size $-10^{6} \mathrm{cfu} / \mathrm{ml}$ ) after incubating at different intervals of time (24, 48, 72, 96 and 120 hours). The fermentation medium was harvested by centrifugation at $5000 \mathrm{rpm}$ for $20 \mathrm{~min}$ at $4^{\circ} \mathrm{C}$ to obtain the crude extract, which served as enzyme source.

\section{Solid state fermentation}

The experiments were conducted in $250-\mathrm{ml}$ Erlenmeyer flasks containing $5 \mathrm{~g}$ of damaged wheat flour (355 microns) substrate moistened with $10 \mathrm{ml}$ of minimal salt solution containing composition $\left(\mathrm{NaCl}-0.8 \mathrm{gL}^{-1} ; \mathrm{KCl}-0.8 \mathrm{gL}^{-1}\right.$; $\mathrm{CaCl}_{2}-0.01 \mathrm{gL}^{-1} ; \mathrm{Na}_{2} \mathrm{HPO}_{4}-2.0 \mathrm{gL}^{-1} ; \mathrm{MgSO}_{4^{-}}$ $0.2 \mathrm{gL}^{-1} ; \mathrm{FeSO}_{4^{-}} 0.1 \mathrm{gL}^{-1}$; Glucose- $8 \mathrm{gL}^{-1}$ and $\mathrm{NH}_{4} \mathrm{Cl}-2 \mathrm{gL}^{-1}$. After sterilization, the flasks were cooled at room temperature and inoculated with a $10 \%(\mathrm{w} / \mathrm{w})$ inoculum and incubated at $37^{\circ} \mathrm{C}$ for $96 \mathrm{~h}$. After fermentation, the entire contents of the flasks were filtered through muslin cloth. The filtrates were pooled together and centrifuged at $10,000 \mathrm{rpm}$ for $15 \mathrm{~min}$ and clear supernatant was used as the crude enzyme source and assayed in terms of saccharifying and dextrinizing activity.

The SA and DA were determined by the methods of (Miller, 1959) and (Fuwa, 1954), respectively.

\section{Results and Discussion}

Isolation and screening of alpha amylase producing microorganisms

Ten bacterial isolates were procured from vegetable farm soil and were coded as isolate $\mathrm{I}_{1}$ to $\mathrm{I}_{10}$. All the ten isolated cultures along with standard cultures Bacillus subtilis (MTCC 121) and Bacillus circulans (MTCC 7906) were assayed for extracellular amylase assay (Aneja, 2012). Out of the ten bacterial isolates, $\mathrm{I}_{5}$ and the two standard cultures 
showed maximum zone of starch hydrolysis and amylolytic activity index was calculated for each colony. Amylolytic activity index was found in Bacillus circulans (2.98) followed by $\mathrm{I}_{5}$ (2.58) and Bacillus subtilis (2.1). The mechanism of clear zone observation was attributed to the fact that amylase produced during the growth of the microorganisms hydrolysed the starch around the colony, thereby testing negative when flooded with iodine. The un-hydrolysed part of the plate tested positive due to the presence of starch (amylose), hence the blue-black appearance. Our results were also in accordance with (Singh and Kumari, 2016) that observed zone of clearance on starch agar media and among five, Bacillus sp. B3 showed the maximum zone of clearance on the starch agar medium i.e., $8 \mathrm{~mm}$. Similarly, Verma et al., (2011) found the maximum amount of amylase production in B. subtilis followed by Bacillus megaterium among nine strains tested which included $B$. cereus, $B$. megaterium and B. subtilis.

\section{Growth kinetics of amylase producing bacterial isolates}

The three bacterial strains viz. Isolate $5\left(\mathrm{I}_{5}\right)$, Bacillus subtilis and Bacillus circulans, were studied for their growth profile in minimal starch medium having soluble starch as a sole carbon source. In Figure 1 the cell growth of all the bacterial strains increased exponentially with increase in incubation period up to 48 hours and then declined till 96 hours of incubation under shaking (120 rpm) conditions. The comparative analysis of growth rate $\left(\mathrm{h}^{-1}\right)$ of Isolate $5\left(\mathrm{I}_{5}\right)$, Bacillus subtilis and Bacillus circulans is shown in Table 1.

Our results are well in line with Mishra and Behera (2008) that reported a soil Bacillus isolate which manifested maximum growth at $48 \mathrm{~h}$ and after that growth declined at $92 \mathrm{~h}$.
Similarly, Vyas et al., (2016) also studied the growth kinetics of $B$. subtilis was done with respect to $\alpha$-amylase production in a basal medium with $\mathrm{pH} 7.0$ at $25 \pm 2^{\circ} \mathrm{C}$. Chandra et al., (1980) reported that composition, incubation temperature and $\mathrm{pH}$ of media greatly affect the growth and production of extracellular amylase production in bacteria. Similarly, (Ho and $\mathrm{Ku}, 2017$ ) reported that $B$. subtilis possessed the maximum specific growth rate at $48 \mathrm{~h}$ with the maximum cell productivity of $1.98 \times 10^{10}$ cells/L/h attained during the exponential growth phase.

\section{Amylase production in submerged fermentation}

In submerged fermentation, highest SA was observed with Bacillus subtilis $(0.62$ $\mathrm{IU} / \mathrm{ml} / \mathrm{min})$ followed by isolate $5(0.58$ $\mathrm{IU} / \mathrm{ml} / \mathrm{min})$ and Bacillus circulans $(0.43$ $\mathrm{IU} / \mathrm{ml} / \mathrm{min}$ ) at 48,48 and 72 hours of incubation period respectively as represented in (Fig. 1).

Maximum DA was found with Bacillus circulans $(1.69 \mathrm{U} / \mathrm{ml})$, followed by isolate 5 (1.65 U/ml) and Bacillus subtilis $(1.02 \mathrm{U} / \mathrm{ml})$ at 72 hours of incubation period respectively (Fig. 1). Further increase in incubation period did not show any significant results with increase in saccharifying and dextrinizing activities. Our results were coherent with AbdElhalem, (2015) who observed that with increase in incubation period, amylase concentration was reduced most probably due to the reduction in nutrients, accumulation of waste product, cell death and catabolite repression. The variation in amylase activities of the isolate could be due to difference in genetic makeup of microorganisms belonging to the same genera and species; it could also be due to the fact that the isolates were obtained from different environments which made them display different amylase activities. 
Table.1 Comparative growth profile, saccharifying and dextrinizing activities of different Bacillus strains in minimal starch medium

\begin{tabular}{|c|c|c|c|c|}
\hline \multirow[t]{2}{*}{ Bacterial strains } & \multirow[t]{2}{*}{ Time (hours) } & \multirow{2}{*}{$\begin{array}{c}\text { Growth rate } \\
\text { Per hour }\end{array}$} & \multicolumn{2}{|c|}{ Maximum amylase activity } \\
\hline & & & $\begin{array}{c}\text { Saccharifying activity } \\
\text { IU/ml/min }\end{array}$ & $\begin{array}{c}\text { Dextrinizing activity } \\
\text { IU/ml/min }\end{array}$ \\
\hline Isolate $5\left(\mathrm{I}_{5}\right)$ & 48 & 0.11 & 0.58 & 1.65 \\
\hline Bacillus subtilis & 72 & 0.12 & 0.62 & 1.02 \\
\hline Bacillus circulans & 48 & 0.22 & 0.46 & 1.69 \\
\hline \multicolumn{2}{|c|}{$\mathrm{CD}(5 \%)$} & 0.13 & 0.49 & 0.58 \\
\hline
\end{tabular}

Table.2 Saccharifying and dextrinizing activities of bacterial strains for alpha amylase production with different substrates under solid state fermentation

\begin{tabular}{|c|c|c|c|c|c|c|c|}
\hline \multirow{2}{*}{$\begin{array}{c}\text { Different } \\
\text { substrates } \\
\text { (@ 1\%) }\end{array}$} & \multirow{2}{*}{$\begin{array}{c}\text { Time } \\
\text { interval } \\
\text { (hrs) }\end{array}$} & \multicolumn{3}{|c|}{$\begin{array}{l}\text { Saccharifying activity } \\
\text { ( } \mu \text { moles } / \mathrm{ml} / \text { minute) }\end{array}$} & \multicolumn{3}{|c|}{$\begin{array}{l}\text { Dextrinizing activity } \\
\qquad(\mathrm{mg} / \mathrm{ml})\end{array}$} \\
\hline & & B. subtilis & B. circulans & Isolate $\left(\mathbf{I}_{5}\right)$ & B. subtilis & $\begin{array}{c}\text { B. } \\
\text { circulans }\end{array}$ & $\begin{array}{c}\text { Isolate } \\
\left(\mathbf{I}_{5}\right)\end{array}$ \\
\hline \multirow{3}{*}{$\begin{array}{l}\text { Raw wheat } \\
\text { flour }\end{array}$} & 48 & $9.65 \pm 0.46$ & $7.32 \pm 2.72$ & $0.81 \pm 0.08$ & $0.10 \pm 0.02$ & $0.09 \pm 0.04$ & $0.01 \pm 0.00$ \\
\hline & 72 & $5.96 \pm 1.03$ & $11.17 \pm 1.37$ & $0.44 \pm 0.09$ & $0.14 \pm 0.03$ & $0.79 \pm 0.18$ & $0.24 \pm 0.05$ \\
\hline & 96 & $5.62 \pm 0.64$ & $12.54 \pm 1.31$ & $0.27 \pm 0.05$ & $0.46 \pm 0.04$ & $1.10 \pm 0.15$ & $0.15 \pm 0.04$ \\
\hline \multirow[t]{3}{*}{ Potato Starch } & 48 & $5.59 \pm 0.41$ & $13.20 \pm 1.56$ & $7.20 \pm 0.47$ & $0.55 \pm 0.20$ & $0.64 \pm 0.08$ & $0.21 \pm 0.07$ \\
\hline & 72 & $5.69 \pm 0.53$ & $14.30 \pm 1.18$ & $6.71 \pm 0.27$ & $0.56 \pm 0.09$ & $1.31 \pm 0.10$ & $0.22 \pm 0.02$ \\
\hline & 96 & $8.00 \pm 0.48$ & $20.00 \pm 2.35$ & $6.41 \pm 0.41$ & $0.63 \pm 0.03$ & $1.79 \pm 0.15$ & $0.22 \pm 0.06$ \\
\hline \multirow[t]{3}{*}{ Corn Starch } & 48 & $7.90 \pm 0.87$ & $9.60 \pm 0.71$ & $2.19 \pm 0.17$ & $0.81 \pm 0.13$ & $0.88 \pm 0.29$ & $3.24 \pm 0.39$ \\
\hline & 72 & $4.60 \pm 0.64$ & $12.06 \pm 1.10$ & $1.09 \pm 0.16$ & $0.84 \pm 0.07$ & $2.25 \pm 0.27$ & $2.62 \pm 0.59$ \\
\hline & 96 & $4.21 \pm 0.63$ & $19.60 \pm 2.70$ & $1.02 \pm 0.09$ & $0.92 \pm 0.07$ & $3.31 \pm 0.36$ & $2.33 \pm 0.29$ \\
\hline \multirow[t]{3}{*}{ Rice Starch } & 48 & $14.65 \pm 2.01$ & $22.00 \pm 3.63$ & $5.45 \pm 0.55$ & $0.18 \pm 0.04$ & $0.28 \pm 0.07$ & $0.76 \pm 0.16$ \\
\hline & 72 & $10.96 \pm 1.44$ & $23.09 \pm 1.12$ & $0.76 \pm 0.05$ & $0.35 \pm 0.06$ & $1.36 \pm 0.06$ & $0.65 \pm 0.10$ \\
\hline & 96 & $5.36 \pm 0.73$ & $23.10 \pm 2.34$ & $0.34 \pm 0.09$ & $0.48 \pm 0.04$ & $1.86 \pm 0.25$ & $0.55 \pm 0.05$ \\
\hline \multicolumn{2}{|c|}{$\mathrm{CD}$ at $5 \%$} & $1.50 \pm 0.14$ & $3.19 \pm 0.13$ & $0.91 \pm 0.06$ & $0.16 \pm 0.02$ & $0.27 \pm 0.05$ & $0.35 \pm 0.10$ \\
\hline
\end{tabular}


Fig.1 Growth profile, saccharifying and dextrinizing activities of Bacillus subtilis, Bacillus circulans and isolate $5\left(\mathrm{I}_{5}\right)$ on minimal starch medium

Fig.1 (a)

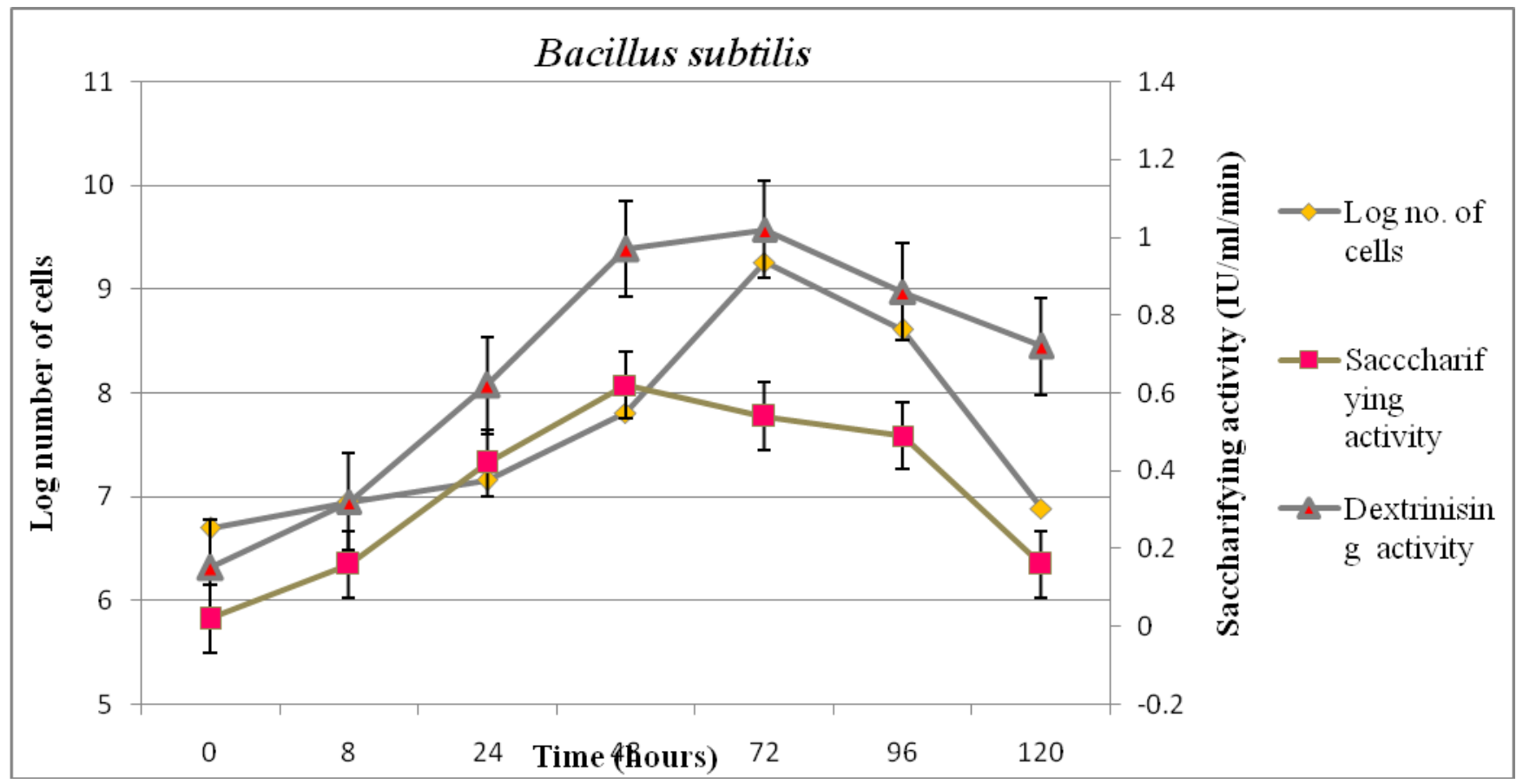

Fig.1 (b)

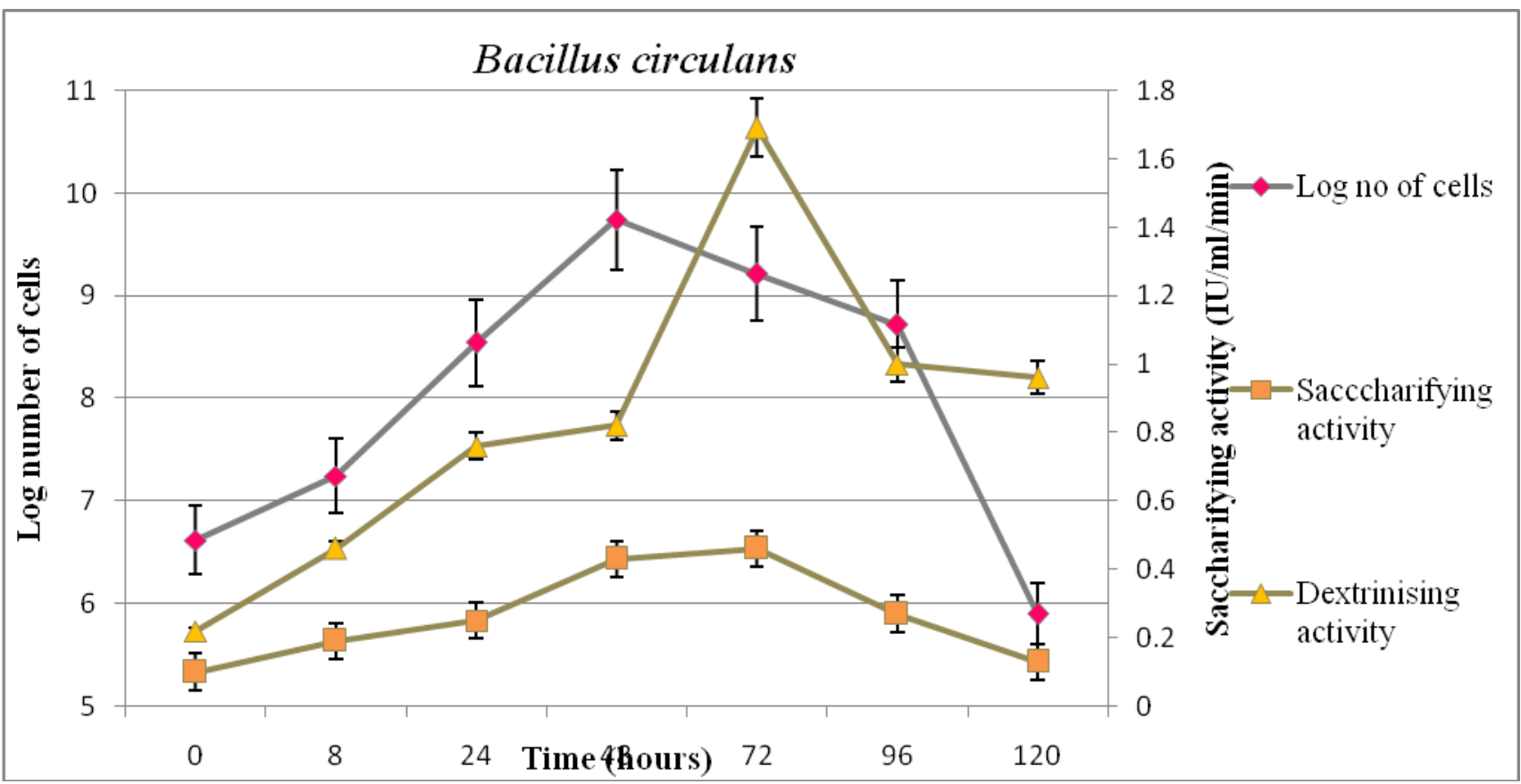


Fig.1(c)

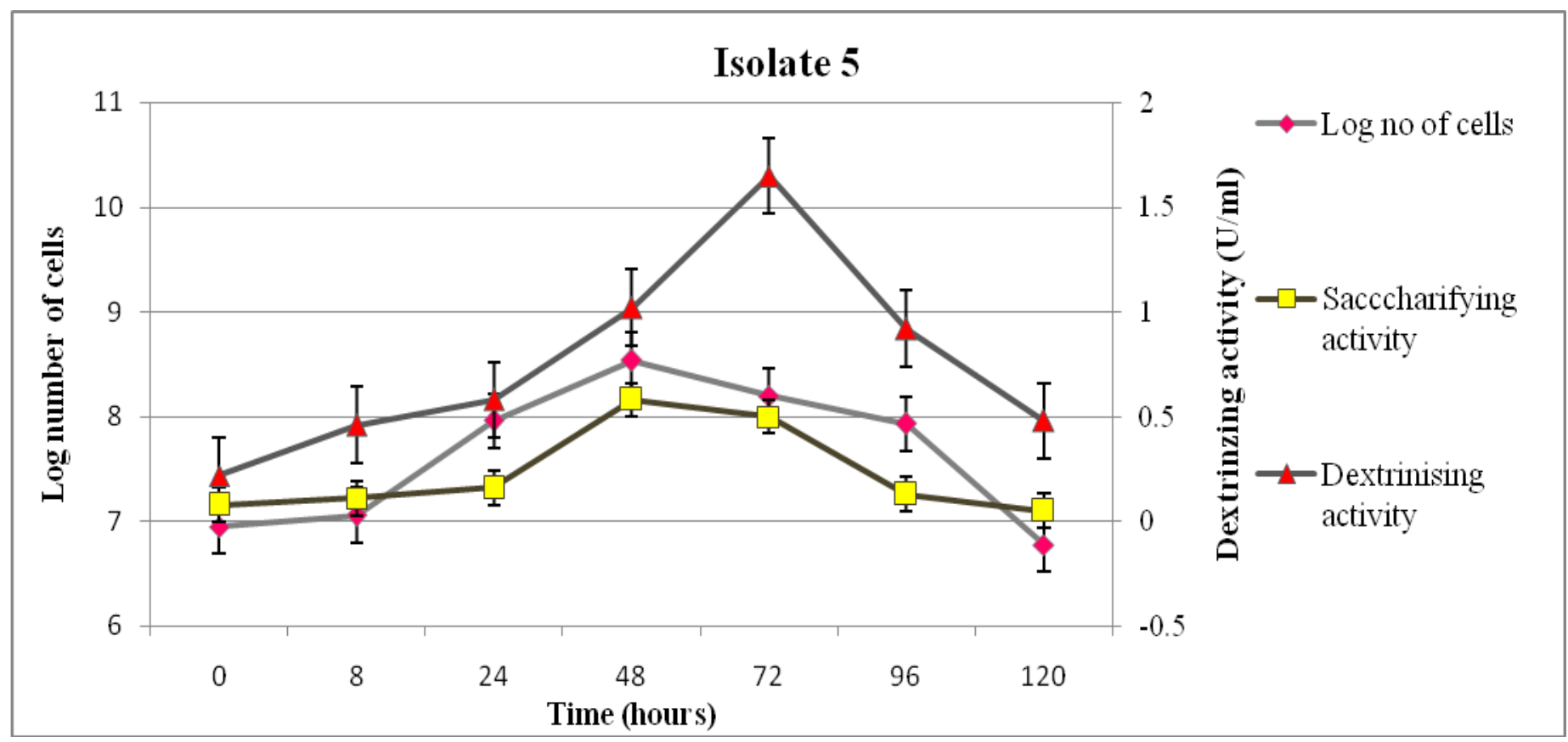

Similarly, Raplong et al., (2014) reported that maximum amylase activity of $2.56 \mathrm{U} / \mathrm{ml}$ was produced by Bacillus cereus $\mathrm{SB}_{2}$ after 24 hours incubation in submerged fermentation. This might be because after $24 \mathrm{hrs}$, the cells reached the decline phase and displayed low amylase synthesis (Sivakumar et al., 2012). Simair et al., (2016) also investigated the time profile of bacterial growth and amylase production in synthetic medium and it was found that maximum dry cell weight $(2.50 \mathrm{~g} / \mathrm{L})$ and amylase enzyme titer $(843 \mathrm{U} / \mathrm{ml})$ was observed at 60 hours after which growth and enzyme titre gradually decreased.

\section{Amylase production in solid state fermentation}

In solid state fermentation, starch content of milled and sieved damaged wheat grains was analysed.

The starch content $(\%)$ of the sieved damaged wheat grains were $1.4 \mathrm{~mm}$ (48.2), 750 microns (48.6), 355 microns (49.2), 180 microns (47.6) and 70 microns (44.89). The relative proportion of starch content was observed to be high in damaged wheat grains, sieved to 355 microns size and was selected for further study.

The three selected bacterial strains viz. Isolate 5 $\left(\mathrm{I}_{5}\right)$, Bacillus subtilis and Bacillus circulans were grown on damaged wheat flour (355 microns size) as a substrate. Among the three strains, maximum saccharifying and dextrinizing activities were demonstrated by Bacillus circulans in the different substrates (potato starch, corn starch, wheat flour and rice starch) mentioned in Table 2. Maximum saccharifying activity was observed (@ 1\% of different substrates) with Bacillus circulans in rice starch $(23.10 \mathrm{IU} / \mathrm{ml} / \mathrm{min})$ followed by potato starch $(20.00 \mathrm{IU} / \mathrm{ml} / \mathrm{min})$, corn starch (19.6 IU/ml/min), and wheat flour (12.54 $\mathrm{IU} / \mathrm{ml} / \mathrm{min}$ ). Whereas, highest dextrinizing activity was recorded (@ 1\% rifferent substrates) with Bacillus circulansin corn starch (3.308U/ml) followed by rice starch $(1.86 \mathrm{U} / \mathrm{ml})$, potato starch $(1.79 \mathrm{U} / \mathrm{ml})$, and wheat flour $(1.10 \mathrm{U} / \mathrm{ml})$.

Our results are in close agreement with Aassaret $a l$. ., (1992) who reported that the alpha amylase enzyme obtained from Bacillus lentus was 
found to be highly active for hydrolysing dextrin (100\%) and starch (96\%), less active on glycogen $(67.26 \%)$ or amylose $(68.92 \%)$, whereas amylopectin (17.20\%) was weakly hydrolysed by the enzyme. Similarly, Farid and Shata (2011) revealed the enzymatic hydrolysis of different carbohydrates (soluble starch, potato starch, corn starch, yellow dextrin and white dextrin) with crude enzyme produced by A. oryzae LS1. Of the substrate tested, soluble starch $(100 \%)$ was the most hydrolyzed by the enzyme. Corn starch $(64.16 \%)$, white dextrin $(34.52 \%)$, yellow dextrin $(29.02 \%)$ and potato starch $(13 \%)$ were also hydrolyzed to a lesser extent. Our results are also coherent with (Elegado and Fujio, 1993) who observed that wheat and cassava starches are the most favoured substrates by all strains while potato and corn starches, the least.

In conclusion, the findings of the current study revealed that, Bacillus circulans being the most potential strain for maximum and cost effective alpha amylase enzyme production at appropriate conditions could be utilized as bio-inoculant in solid state fermentation as compared to submerged fermentation technology in sustainable manner.

\section{References}

Aassar, S. A. E., S. H. Omar, M. K. Gouda, A. M. Ismail and Abdel-Fattah, A. F. 1992. Purification of $\alpha$-amylase from Bacillus lentus cultures Applied Microbiology and Biotechnology. 38: 312-314.

Abd-Elhalem, B. T., M. El-Sawy, R. F. Gamal, and AbouTaleb, K. A. 2015. Production of amylases from Bacillus amyloliquefaciens under submerged fermentation using some agro-industrial by-products. Annals of Agricultural Sciences. 60(2): 193-202.

Aneja, K. R. 2012. Experiment in microbiology, plant pathology, tissue culture and mushroom production technology. New age international publishers., pp. 169171.

Chandra, K., S. Medda and Bhadra, A. K. 1980.
Production of extracellular thermostable $\alpha$-Amylase by Bacillus lichenifermis. Journal of Fermentation Technology. 58(1):1-10.

Clegg, K. M. 1956. The application of anthrone reagent to the estimation of starch in cereals. Journal of Food Science and Technology. 7:40-44.

Elegado, F.B. and Fujio, Y. 1993. Selection of raw starch digestive glucoamylase producing Rhizopus strain. Journal of General Applied Microbiology. 39: 5401-5406

Farid, M. A. F., H Mohamed and Shata, A. H. 2011. Amylase production from AspergillusoryzaeLS1 by solid-state fermentation and its use for the hydrolysis of wheat flour. Iranian Journal of Biotechnology. 9(4): 267274.

Fuwa, H. 1954. A new method of microdetermination of amylase activity by the use of amylase as the substrate. Journal of Biochemistry. 41: 583-603.

Ho, H. L. and $\mathrm{Ku}, \mathrm{X}$. N. 2017. Kinetic study of cell growth and production of amylase, cellulase and xylanase by Bacillus subtilis using barley husk as the prime carbon source. Journal of Advances in Biology \& Biotechnology 14(2): 1-18.

Lonsane, B. K. and Ramesh, M. V. 1990. Production of bacterial thermostable $\alpha$ amylase by solid-state fermentation: a potential tool for achieving economy in enzyme production and starch hydrolysis. Advanced Applied Microbiology. 35:1-56.

Mageshwaran, V.,F. Inmann and Holmes, L. D. 2014. Growth kinetics of Bacillus subtilis in lignocellulosic carbon sources. International Journal of Microbiology Research. 6(2): 570-574.

Miller, G. L. 1959. Use of dinitro-salicylic acid reagent for determination of reducing sugar. Analytical Chemistry. 31: 426428.

Mishra, S. and Behera, N. 2008. Amylase activity of a starch degrading bacteria isolated from soil receiving kitchen 
wastes. African Journal of Biotechnology. 7(18): 3326-3331.

Pandey, A., C. R. Soccol, and Mitchell, D. 2000. New developments in solid state fermentation: I-bioprocesses and products. Process Biochemistry. 35: 1153-1169.

Pandey, A., P. Selvakumar, C. R. Soccol, and Nigam, P. 1999. Solid state fermentation for the production of industrial enzymes. Current Science. 77:149-162.

Raplong, H. H., P. O. Odeleye, C. Hammuel, M. O. Idoko, J. I. Asanato, E. H. Odeke. 2014. Production of alpha amylase by Bacillus cereus in submerged fermentation. Aceh International Journal of Science and Technology 3(3): 124130.

Rehman, A and Saeed, A.2015.Isolation and screening of amylase producing Bacillus species from soil. International Journal of Advanced Research 3(4): 151-164

Ryan, S. M., G. F. Fitzgerald and Sinderen, D. V. 2006. "Screening for and identification of starch-, amylopectin and pullulan degrading activities in Bifido-bacterial Strains. Applied and Environmental Microbiology. 72(8): 5289-5296.

Sharon, M. E. M., C. V. K. Abirani and Alagusundaram, K. 2014. Grain storage management in India. Journal of Post Harvest Technology. 2:12-24.

Simair, A. A., A. S. Qureshi, I. Khushk, C. H.
Ali, S. Lashari, M. A. Bhutto, G. S. Mangrio and $\mathrm{Lu}, \mathrm{C}$. 2017. Production and partial characterization of $\alpha$ Amylase enzyme from Bacillus sp. BCC 01-50 and potential applications. BioMed Research International. 6(2):110.

Singh, P and Kumari, P. 2016. Isolation and characterization of amylase producing Bacillus spp. from selected soil sample. International Journal of Research in Biosciences. 5(2): 24-29.

Sivakumar, T., T. Shankar, P. Vijayabaskar, J. Muthukumar, and Nagendrakannan, E. 2012. Amylase production using Bacillus cereus isolated from a vermicompost site. International Journal of Microbiological Research. 3(2): 117123.

Verma, V., M. S. Avasthi, A. R. Gupta, and Kushwaha, A. 2011. Amylase production and purification from bacteria isolated from a waste potato dumpsite in district Farrukhabad U.P state India. European Journal of Experimental Biology. 1(3): 107-113.

Vyas, P., M. Shirsat and Singh, S. 2016. Growth activity and alpha-amylase production by Bacillus Subtilis NICM 2479 to study their effect on maize kernel starch. International Journal of Pharmaceutical \& Biological Archives. 7(2): 29-34.

\section{How to cite this article:}

Nadia Razdan and Kocher, G.S. 2018. Isolation and Characterization of Bacteria for Amylase Production under Solid State Fermentation Using Damaged Wheat as Substrate. Int.J.Curr.Microbiol.App.Sci. 7(07): 946-955. doi: https://doi.org/10.20546/ijcmas.2018.707.114 